\title{
National development level effects on capital budgeting practices: a comparative study of nature vs nurture
}

\author{
Pratheepkanth Puwanenthiren \\ University of Jaffna, Jaffna, Sri Lanka
}

Received 23 August 2021 Revised 21 November 2021 7 December 2021

\begin{abstract}
Purpose - This research should help determine whether development should focus on individual firms or will raising the national development level act like a rising tide and raise the performance of all corporations.

Design/methodology/approach - The comparative data used in this study come from 150 Australian (ASX200 index listed) firms and 150 Sri Lankan (Colombo Stock Exchange listed) firms. The research questions are answered via a quantitative research design that uses primary and secondary data.

Findings - The findings demonstrate that capital budgeting practices are more influenced by contingency features and sophistication in Australia and Sri Lanka. Also, Australian firms tend to use capital budget models with good-to-strong predictive power (except for $R O E$ ) and Sri Lankan firms tend to use capital-budget models with fair-to-poor predictive power. Further, the analysis of Australian firms yielded much stronger and more statistically significant results than the analysis of Sri Lankan firms.

Practical implications - In complex real-world situations, reconciling the outputs of a multifaceted approach to capital budgeting methods is more likely to give the depth and width of input needed to achieve an optimal capital investment plan.

Originality/value - The results of this study can provide rich information for stakeholders about new findings in capital budgeting $(\mathrm{CB})$ practices and their contributions to firm performance in a comparative perspective.
\end{abstract}

Keywords Capital budgeting, Discounted cash flow, Non-discounted cash flow

Paper type Research paper

\section{Introduction}

\subsection{Capital budgeting and firm performance}

According to the traditional theory of the firm, the firm's objective is to maximise shareholder wealth (Gervais et al., 2012). Capital budgeting, a key input to maximising shareholder wealth, is the rational allocation of limited capital across a plethora of viable prospective investments (Bennouna et al., 2010; Gervais et al., 2012; Proctor and Canada, 1992). As such, capital budgeting $(C B)$ is defined as the evaluation of investment prospects in long-term assets (Peterson and Fabozzi, 2002; Van Horne et al., 1995).

Effective capital-investment budgeting and management is key to optimal firm performance (Arnold and Hatzopoulos, 2000; Farragher et al., 1999). Such processes enhance capital-investment decisions by assuring that corporate strategies are known and followed, available investment opportunities are considered and unplanned/unjustified

\section{JEL Classification - G10, G11 and G31}

(C) Pratheepkanth Puwanenthiren. Published in PSU Research Review. Published by Emerald Publishing Limited. This article is published under the Creative Commons Attribution (CC BY 4.0) licence. Anyone may reproduce, distribute, translate and create derivative works of this article (for both commercial and non-commercial purposes), subject to full attribution to the original publication and authors. The full terms of this licence may be seen at http://creativecommons.org/licences/by/4.0/ legalcode.

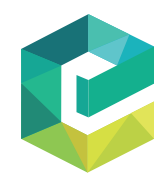

PSU Research Review Emerald Publishing Limited DOI 10.1108/PRR-08-2021-0043 
decision making is minimised. Studies on CB suggest that firms are increasingly employing more refined $\mathrm{CB}$ techniques for investment decisions (Arnold and Hatzopoulos, 2000; Farragher et al., 2001; Kashyap, 2014; Klammer and Walker, 1984; Klammer, 1973; Mustapha and Mooi, 2001; Ruhan, 1998; Wnuk-Pel, 2014). Vadeei et al. (2012), Hasan et al. (2011), Farragher et al. (2001), Haka et al. (1985), Pike (1984) and Kim (1981) researched extensively into links between $\mathrm{CB}$ and firm performance.

This research contributes to the extant $\mathrm{CB}$ literature by considering the relative importance of a firm's nature vs the nurture of its national environment (e.g. development level of the nation in which the firm is embedded). This is a vital issue for CB management in firms and for directing development efforts in less developed nations. Specifically, as previously noted, good $\mathrm{CB}$ practices play a vital role in enhancing firm performance. Given that firms are contributors to Gross Demostic Product $(G D P)$, the quality of firm $\mathrm{CB}$ practices can create and perpetuate a virtuous/(vicious) cycle of rising/(falling) firm and national performance (Chen, 1991). This is one of a few studies that contain a comparative perspective of the CB practises of firms in a developed nation with firms in an emerging nation (Brounen et al., 2004; Peel, 1999; Graham and Harvey, 2001; Hermes et al., 2007). The two countries under consideration in this study are Australia and Sri Lanka:

Australia is a developed nation with: a relatively small open economy, a population of 23.7 million residents, business practices and regulation that are respected (e.g. its Corruption Perceptions index $(C P I)$ is $80 / 100$ where 100 is no corruption), with institutions that helped to comfortably weather the Global Financial Crises $(G F C)$.

Sri Lanka is an emerging country with: a rapidly growing economy (after the 30 year civil war ended in 2009), a population of 20.48 million residents, ongoing economic reforms, a mid to high level of corruption (e.g. its CPI is 38/100), and major effort to reintegrate into international markets.

The paper is organised as follows. Section 2 reviews literature on CB practices and firm performance; Section 3 provides the methodology of the research and also discusses the firm and its managers' features; Section 4 discusses findings; and Section 5 gives the conclusions, limitation of the study and suggestions for future research.

\section{Literature review}

As noted previously, CB is a key driver of investment choice and implementation (Kashyap, 2014; Farragher et al., 2001). As a result, CB contributes to maximising stakeholder value. The corporate finance literature distinguishes two key concepts in $\mathrm{CB}$ : $\mathrm{CB}$ processes and $\mathrm{CB}$ technqiues. $\mathrm{CB}$ processes explain how firms treat investment decisions in practice (Batra and Verma, 2014; Farragher et al., 2001). On the other hand, CB technqiues are defined as the methods and techniques used to evaluate and select an investment (Bennouna et al., 2010).

\subsection{Capital budgeting process}

The $\mathrm{CB}$ process, by improving investment decisions quality and implementation (Kashyap, 2014; Farragher et al., 2001), helps to maximise stakeholder wealth (Andor et al., 2015). In this context, Pinches (1982) and Mintzberg et al. (1976) emphasised a CB model that encompasses identification, development, selection and control stages. The identification stage, per Northcott (1995), provides recognition of an opportunity for investment. The identified investments should be subjected to preliminary screening by management, to separate unreliable investments. If an investment survives the analysis phase, a judgement is then made to accept or reject the investment. Once the investment passes the acceptance phase, it should be implemented by management. Post-audit reviews create useful feedback to the investment appraisal process. 
Lam et al. (2008), Farragher et al. (2001), Han (1986) and Kim (1981) focus on the CB process from different perspectives (e.g. Farragher et al. (2001) examined the impact of sophisticated CB practices on corporate performance in the USA; Kim (1981) tested the empirical relationship between $\mathrm{CB}$ practices and earnings performance. This is one of a few studies that concentrates on the $\mathrm{CB}$ processes in comparative perspective.

\subsection{Capital budgeting techniques}

The selection of appropriate $\mathrm{CB}$ techniques for investment decisions is a key managerial activity (Wnuk-Pel, 2014). CB-technique-focused studies have an extensive tradition in corporate finance literature. Mainly these researches focus on developed nations (e.g. the USA: Graham and Harvey (2001), Shao and Alan (1996); Canada: Baker et al. (2011), Bennouna et al. (2010), Vijay and Ashwani (1995), the UK: Alkaraan and Northcott (2006), Arnold and Hatzopoulos (2000); and Australia: Truong et al. (2008), Freeman and Hobbes (1991). Graham and Harvey (2001) investigated the theory and practice of corporate finance in USA. They interviewed 392 chief financial officers (CFOs) about capital structure, cost of capital and CB and found the most popular evaluation techniques were net present value (NPV) and internal rate of return (IRR). Also, Discount cashflow (DCF) techniques and capital asset pricing model (CAPM) are increasingly used by large firms to evaluate $\mathrm{CB}$ and that small firms tend to use less sophisticated techniques. DCF has become the main appraisal technique in Canada (Bennouna et al., 2010; Jog and Srivastava, 1995; Vijay and Ashwani, 1995). In particular, the use of DCF appears to have increased from a low of around 35\% in the early 1960s to over $90 \%$ in the early 1990s. NPV is now widely used among Candian firms, but a sizeable percentage use IRR as their primary model in capital decision-making (Bennouna et al., 2010). In the UK, Pike (1988) noted that the use of DCF methods had increased from 58 to $84 \%$ from 1975 to 1986 . However, the PBP method is still widely used in the UK, and DCF seems to have also increased (Alkaraan and Northcott, 2006). Freeman and Hobbes (1991) found DCF techniques increased in use in Australia from 52 to $75 \%$ between 1979 and 1989 . Truong et al. (2008) found that $94 \%$ of CFOs in their survey used NPV, followed by PBP and IRR. They also found that real-options analysis is gaining relevance in Australia $\mathrm{CB}$, but it is not yet a mainstream method.

Only a limited number of studies emphasise CB evaluation techniques in emerging countries (e.g. Malaysia, Indonesia, China and Singapore) which were considered by Farah et al. (2008), Chan et al. (2004) and Kester and Chong (1998); African economies were reviewed by Maroyi and Van Der Poll (2012), Hassan et al. (2011), Pradeep and Lemay (2009), Sulaiman (2007) and Coltman (1995); India was looked by Manoj (2002), Satish et al. (2009), Singh et al. (2012). Some earlier studies of CB practices in Southeast Asia (Malaysia, Hong Kong, Philippines and Singapore) ascribe equal significance to DCF and Non-Discount Cashflow (NDCF) methods. It appears that Asian and African CFOs tend to rely more on NDCF methods than sophisticted methods, when selecting long-term investments.

\subsection{Capital budgeting practices and firm performance}

Financial theory suggests that sophisticated CB systems should enhance firm performance, but this assertion appears to have had only limited empirical testing. Vadeei et al. (2012), Farragher et al. (2001), Pike (1984), Kim (1981) and Klammer (1973) looked at the impact of CB on firm performance. Klammer (1973), in a survey of 369 USA manufacturing firms, found no significant relationship between CB techniques and firm performance. In contrast, Kim (1981) and Vadeei et al. (2012) found a positive association between the CB process and firm performance. In other research, Pike (1984) found a negative association between CB evaluation techniques and firm performance and Farragher et al. (2001), Pike (1984), and Christy (1966) found no significant relationships between the sophistication of CB processes 
and firm performance. Thus, for the most part, these studies have focused on the application and enhancement of the modelling techniques applied. The trend towards the adoption of more refined $\mathrm{CB}$ practices has led researchers to consider whether these refinements have enhanced performance and profitability. The mixed outcomes of that research suggest that a significant gap exists in understanding the nature, intensity and direction of the relationship between $\mathrm{CB}$ practises and performance. Further, the relationship between firm performances and different variables are analysed by researchers (Aldamen et al., 2012; Aldamen and Duncan, 2012), the impact of CB process, techniques, nature of firms and the development level of the country on firm performances are yet to be researched.

\section{Methodology}

In addressing the gap discussed in the previous section, this study focuses on two key drivers of CB sophistication: (1) the relative sophistication of the firms conducting the CB and (2) the development level of the nations in which the firms are embedded. This issue is essentially nature vs nurture. Specifically, does nature of a firm trump the nurture of the development level of the nation in which it is embedded?

Initially, the population of interest in this study was 200 Australian Securities Exchange $(A S X)$ listed firms (S\&P/ASX200) and 289 Colombo Stock Exchange (CSE) listed firms. In selecting the study population, this study excludes financial, investment and securities-sector firms, because their unique financial attributes, intensity of regulation, and/or intensive use of leverage are likely to confuse and/or foul the outcomes being studied. Also, the risk of missing data was reduced by excluding firms that were not listed throughout the review period. After the eliminations, the remaining population was 150 Australian ASX-listed firms and 150 Sri Lankan CSE-listed firms. The results of the questionnaire survey of firms was, respectively, 45 completed questionnaires from Australia and 73 from Sri Lanka, giving an effective response rate of, 31.5 and $48.7 \%$, respectively. Secondary data were obtained in recent five years, and ASX, CSEs and SIRCA databases were used to calculate return on assets $(R O A)$, return on equity $(R O E)$, Tobin's $\mathrm{Q}(T Q)$ and earnings per share $(E P S)$ for the relevant firms.

Data were collected in two phases. The first phase constituted a structured survey questionnaire which was followed by a second phase of gathering the appropriate financial statements for the relevant period. The integration of multi-method data collection was seen to offer a deeper insight into the research findings. A quantitative research design utilising both primary and secondary data was used to answer the research questions.

In phase one, a structured questionnaire survey was used to explore the $\mathrm{CB}$ practices of Australian and Sri Lankan firms as an example of a developed and emerging market. The questionnaire sought information on the $\mathrm{CB}$ practices of the responding firms and included two types of questions. The first set of questions sought to describe attributes of the firm and its respondents while the second set investigated attributes of the $\mathrm{CB}$ practice. Phase one gives a descriptive study of CB practices in Australian and Sri Lankan listed firms and the comparison of those $\mathrm{CB}$ practices and techniques identifies similarities and differences in the practices between firms in a developed (Australia) and emerging economy (Sri Lanka). Phase one sought to determine, whether CB practices differed significantly between Australia and Sri Lanka firms and if any differences can be explained by differences in levels of national economic development after adjusting for conflating factors such as firm and CFO attributes.

Phase two examines $\mathrm{CB}$ practices via the lens of a process approach and an evaluation approach; which allows for a connection between these different perspectives and firm performance in Australian- and Sri Lankan-listed firms. Phase two links the primary data gathered in phase one with secondary data, annual reports of the relevant firms during 200716 , taken from the ASX, CSE's and SIRCA database to provide ROA, ROE, TQ and EPS. The intention of phase two is to explore for relationships between (on one hand) the CB process 
and choice of appraisal techniques used by developed and emerging countries and (on the other) firm performance (both from an accounting and a market perspective). It was considered that these findings would assist CFOs in shedding light on the numerous corporate finance theories associated with firm performance and the stakeholders' wealth of the firm in Australia and Sri Lanka. Thus, the data used in the quantitative stage of this study was gathered in two phases:

\subsection{Measurement of variables}

3.1.1 Capital budgeting process of firm $\mathrm{j}\left(C B P_{j}\right)$. Following an approach used by Batra and Verma (2014), Farragher et al. (2001), Pike (1984) and Kim (1981), the CB sophistication of firm respondents was defined via:

$$
C B P_{j}=\sum_{K=i}^{n}\left(S_{j k}\right)\left(W_{k}\right)
$$

where $S_{j k}=$ Score for CB for firm $j$, activity $k$

$W_{k}=$ Weighting for $\mathrm{CB}$ activity $k$

Building of $C B P_{j}$ is done in two stages:

(1) A constructing weight $\left(W_{k}\right)$ for each country that used the mean values of each $\mathrm{CB}$ activity. Respondents were asked to rate the importance of each $\mathrm{CB}$ activity on a Likert $0.0-5.0$ scale, with 5.0 being "strongly agree". The mean based on 45 Australian respondents and 73 Sri Lankan respondents are listed in Table 1 . The weights $\left(W_{k}\right)$ were estimated by dividing the mean score for each activity by the total mean score for all activities. Table 1 lists the mean and weight $\left(W_{k}\right)$ for Australia and Sri Lanka.

(2) Constructing $S_{j k}$ - The score for CB activity $k$ for firm $j\left(S_{j k}\right)$ is measured using 0-1 Likert scale and considers whether or not a firm conducts each of the components of that activity.

$$
S_{j k}=\sum_{K=i}^{n}\left(X_{i}\right) /(N)
$$

where $X_{i}=$ Score for each component, as defined in Eq. (3).

$$
N=\text { Total number of component activity }
$$

\begin{tabular}{lcccc}
\hline & \multicolumn{2}{c}{ Australia } & \multicolumn{2}{c}{ Sri Lanka } \\
Capital budgeting activity & Mean & Weight $\left(W_{k}\right)$ & Mean & Weight $\left(W_{k}\right)$ \\
\hline Long-term investment planning & 4.044444 & 13.76702 & 4.315068 & 14.52952 \\
Search for investment opportunities & 4.266667 & 14.52345 & 4.123288 & 13.88376 \\
Review and screening & 4.022222 & 13.69138 & 3.808219 & 12.82288 \\
Accept/reject decisions & 4.555556 & 15.50681 & 4.465753 & 15.0369 \\
Implementation & 4.155556 & 14.14523 & 4.493151 & 15.12915 \\
Expenditure control and monitoring & 4.022222 & 13.69138 & 4.136986 & 13.92989 \\
Post-audit & 4.311111 & 14.67474 & 4.356164 & 14.6679 \\
Total & 29.37778 & 100 & 29.69863 & 100
\end{tabular}

Table 1. Weights for capital budgeting activities 
3.1.2 Capital budgeting techniques (CBT). The selection of $\mathrm{CB}$ techniques is explained as the commonly used appraisal methods by firms (or dummy which takes the value of 1 if the firm is using at least two or more of $\mathrm{CB}$ techniques and the value 0 otherwise).

$$
C B T_{j}=X_{i}
$$

where $X_{i}=1$ if respondent conducts $\geq 2 \mathrm{CB}$ techniques.

$$
X_{i}=0 \text { if respondent conducts } \leq 1 \mathrm{CB} \text { techniques }
$$

3.1.3 Firm's features. In this study firm size, income source (domestic or overseas) ownership (domestic or foreign) and risk level are considered as firm features. Table 2 defines how dummy variables were used in the analysis.

3.1.4 CFO's attributes. In this study, the CFO's highest education attained, age and experience are considered CFO characteristics. Table 3 below shows the use of dummy variable in the calculation process.

Statistical analysis of the quantitative results were done using social science software 22.1 (SPSS) and includes descriptive statistics, multiple regression analysis, analysis of variance and $t$-test. The following multiple regression model equations examined the association between $\mathrm{CB}$ practices and firm performance.

$$
\begin{aligned}
R O A(\text { performance })= & a_{0}+a_{1} C B P_{j}+a_{2} C B T_{j}+a_{3} E D U+a_{4} A G E+a_{5} E X P \\
& +a_{6} S O E+a_{7} D I+a_{8} O W N+a_{9} R L+\varepsilon \\
R O E(\text { performance })= & b_{0}+b_{1} C B P_{j}+b_{2} C B T_{j}+b_{3} E D U+b_{4} A G E+b_{5} E X P \\
& +b_{6} S O E+b_{7} D I+b_{8} O W N+b_{9} R L+\varepsilon \\
E P S(\text { performance })=c_{0}+ & c_{1} C B P_{j}+c_{2} C B T_{j}+c_{3} E D U+c_{4} A G E+c_{5} E X P+c_{6} S O E \\
+ & c_{7} D I+c_{8} O W N+c_{9} R L+\varepsilon \\
T Q(\text { performance })= & d_{0}+d_{1} C B P_{j}+d_{2} C B T_{j}+d_{3} E D U+d_{4} A G E+d_{5} E X P \\
& +d_{6} S O E+d_{7} D I+d_{8} O W N+d_{9} R L+\varepsilon
\end{aligned}
$$

where $a_{0}, b_{0}, c_{0}, d_{0}=$ Constant terms.

\section{Table 2.}

Dummy variables used Ownership to study firm features
Number of employees Income source background

Table 3. CFO's age

Use of dummy variables for CFO's attributes

CFO's experience
Dummy variables would either take the value of 1 if the firm belongs to the more than 500 employees, otherwise it would take the value of 0

Dummy variables would either take the value of 1 if the firm belongs to the more than $80 \%$ domestic income, otherwise it would take the value of 0

Dummy variables would either take the value of 1 if the firm belongs to the domestic ownership, otherwise it would take the value of 0
Dummy variables would either take the value of 1 if the managers who have master degree or more, otherwise it would take the value of 0

Dummy variables would either take the value of 1 if the manager ages between 55-65 category, otherwise it would take the value of 0

Dummy variables would either take the value of 1 if the manager who has been in their position longer than 10 years; otherwise it would take the value of 0 


$$
\begin{aligned}
& a_{1-9}, b_{1-9}, c_{1-9}, d_{1-9}=\text { Regression coefficients } \\
& C B P_{j}=\text { Capital budgeting practices for firm } j \\
& C B T_{j}=\text { Choice of capital budgeting techniques for firm } j \\
& E D U=\text { CFO Education } \\
& A G E=\text { CFO Age } \\
& E X P=\text { CFO Experience } \\
& S O E=\text { Firm Size of employees } \\
& D I=\text { Firm Domestic income } \\
& O W N=\text { Firm Ownership } \\
& R L=\text { Firm Risk level } \\
& \varepsilon=\text { error term }
\end{aligned}
$$

\section{Capital budgeting}

\subsection{Sample: firm and CFO's attributes}

Figure 1a-d summarise the information on the firm features (i.e. industry sectors, employee numbers, domestic income and ownership). A majority of sample firms are in the consumer staples industry sector (22 and $28 \%$ in, respectively, Australia and Sri Lanka), and the lowest representation is in the information and utilities sector (respectively, 3 and $2 \%$ in Australia and Sri Lanka). Figure 1b illustrates that $89 \%$ of Australian firms have over 500 employees, and $64 \%$ of Sri Lankan firms have over 500 employees. Australian and Sri Lankan firms accounted more than one-half respondents (i.e. 62 and $64 \%$ of total respondents have more than $80 \%$ of domestic income respectively). Figure $1 d$ shows that 92 and $67 \%$ are domestically-owned firms in, respectively, Australia and Sri Lanka. However, foreign ownership of firms in both countries is similar.

Figure 2a-d display CFO's profiles (i.e. gender, education, age and experience). There are mostly male CFOs (80 and 89\%, respectively, in Australia and Sri Lanka) with 63 and $44 \%$ of, respectively, Australian and Sri Lankan CFOs holding a bachelor or honours degree as their highest level of education accomplishment. Further, $55 \%$ of Australian CFOs are under 35 years of age. In contrast, $84 \%$ of the CFOs of Sri Lanka respondent firms are over 36 and less than $16 \%$ are under 35 . Finally, only $31 \%$ of Australia CFOs have been in their positions 6 to 10 years. In contrast, $44 \%$ of the CFOs of respondent Sri Lanka firms have over 16 years' experience.

\section{Results and discussion}

\subsection{Independent samples t-test}

4.1.1 Capital budgeting process-Australia and Sri Lanka. This section examines the way in which Australian and Sri Lankan firms evaluate investments. CB practices examined are CB process (e.g. long-term strategic planning, search for investment opportunities, review and screening, accept/reject decisions, implementation, expenditure control and monitoring, and post-audit and $\mathrm{CB}$ appraisal techniques (including investment analysis techniques, risk analysis techniques and cost of capital). Table 4 indicates that there are significant differences between Australia and Sri Lanka in the use of CB process except search for investment opportunities, review and screening, and accept/reject decisions as indicated by the $t$-values such as long-term strategic planning $(t=-2.698, p<0.05)$, implementation $(t=-4.931, p<0.05)$, expenditure control and monitoring $(t=-4.347, p<0.05)$ and post- 
PRR

Figure 1.

(a-d) Features of firms in the sample (Australia and Sri Lanka)
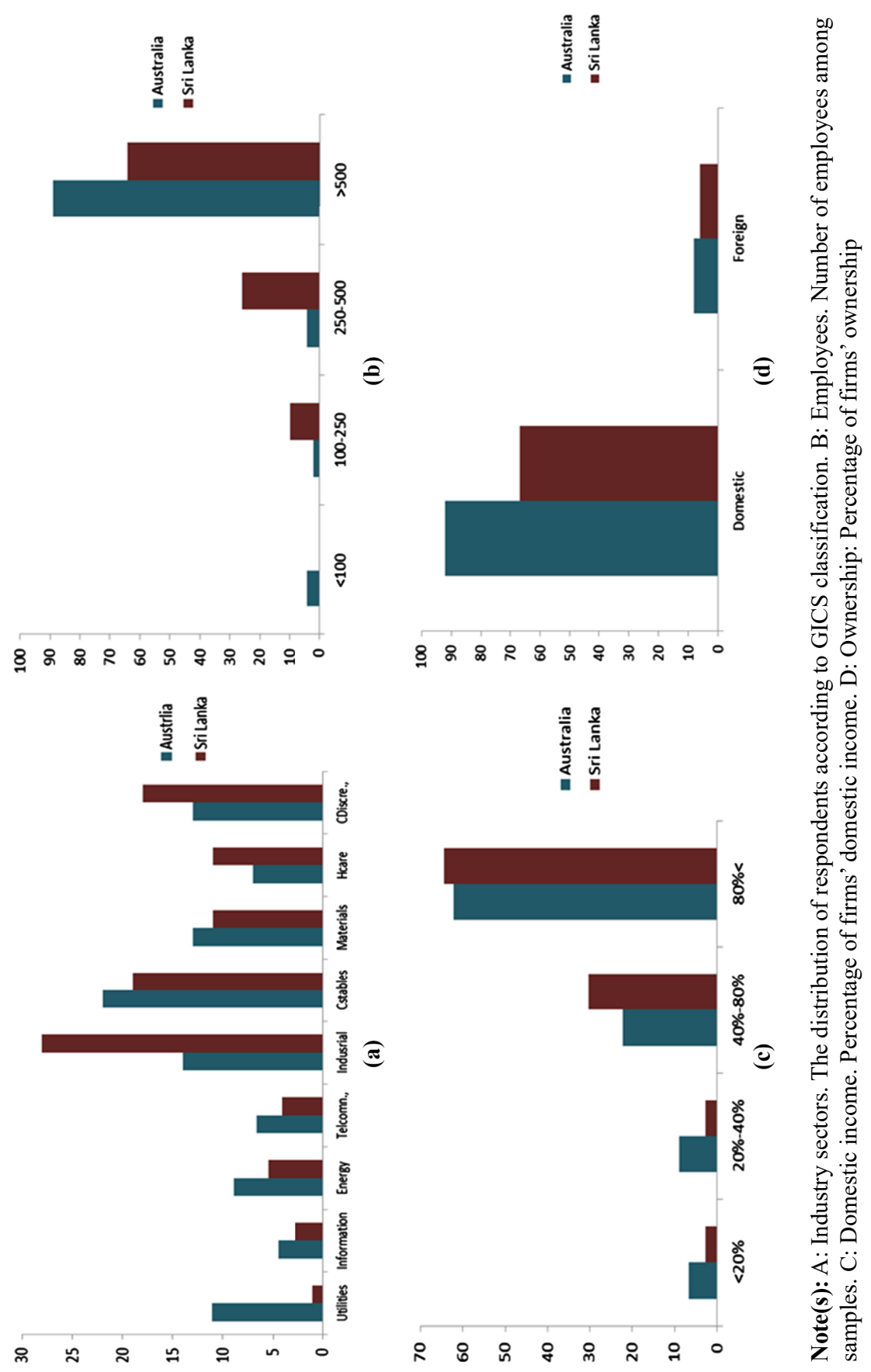


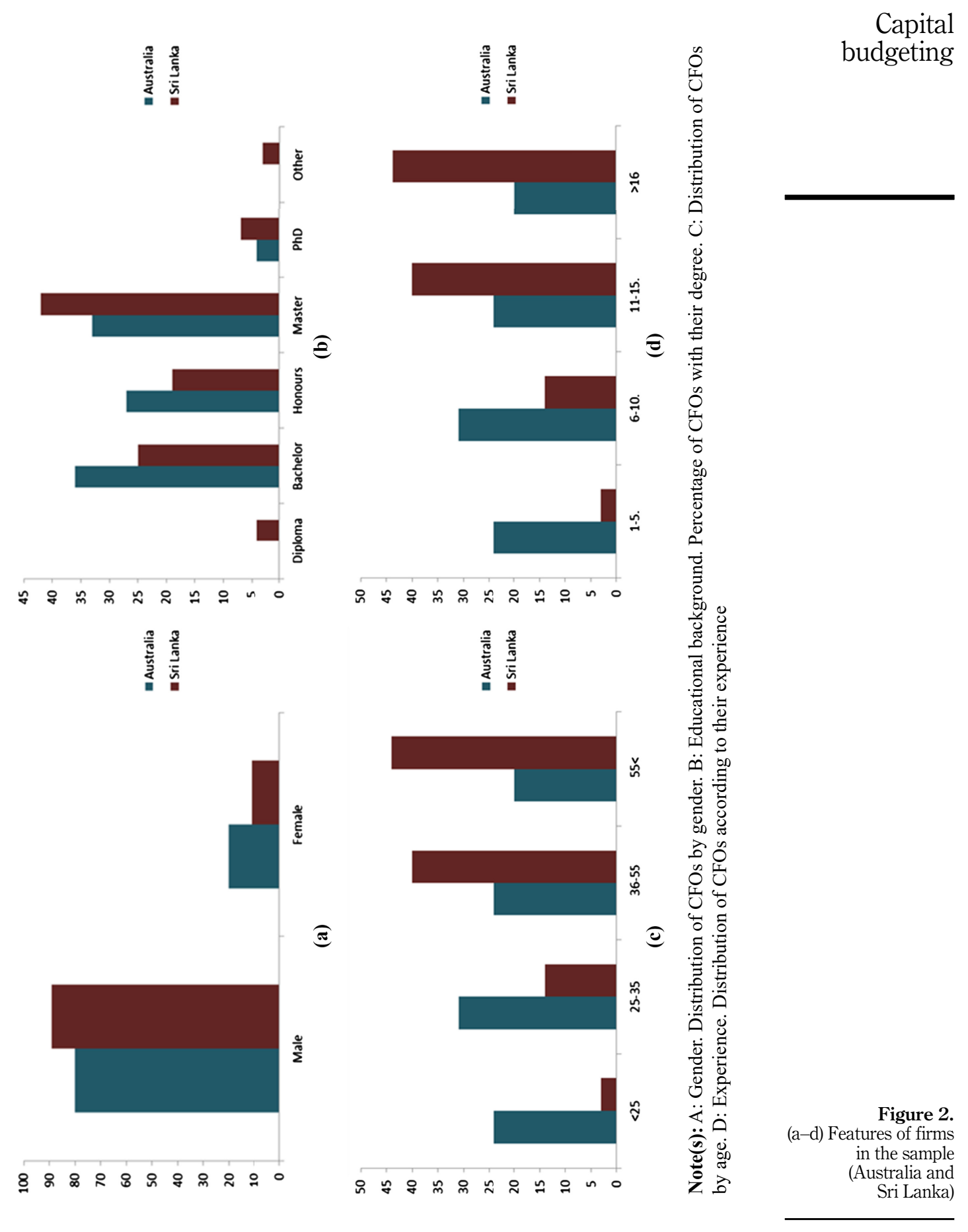


audit $(t=-2.860, p<0.05)$. In Australia, search for investment opportunities and implementation are found to be the most comparatively important stages of CB compared with Sri Lanka. It can, therefore, be concluded that the country settings somewhat affect the CB process in Australian and Sri Lankan firms.

In Australia, the differences between male and female CFOs in the use of $\mathrm{CB}$ process are not significant, other than in the review and screening phase $(t=2.098, p<0.05)$. In Sri Lanka, there are no significant differences between male and female CFOs in the use of CB process. Also, there are no significant differences between domestic- and foreign-owned firms in the use of CB practices in Australia or in Sri Lanka, except in Australia the accept/reject decisions $(t=2.296, p<0.05)$ and implementation $(t=-2.817, p<0.05)$.

4.1.2 Investment analysis techniques-Australia and Sri Lanka. Table 5 suggests significant differences between Australia and Sri Lanka on usage of CB techniques such as ARR $(t=2.205 ; p<0.05)$, NPV $(t=6.987 ; p<0.05)$ and IRR $(t=6.221 ; p<0.05)$. This result can be interpreted as supportive evidence for the fact that Australian CFOs seem to use NPV, IRR and ARR methods more often than CFOs in Sri Lanka. Although PBP preference is consistently stronger in Sri Lanka, it does not differ significantly from $\mathrm{CB}$ techniques of Australian firms. This result is consistent with the study conducted by Hermes et al. (2007) who reported that Dutch firms tend to use more extensive CB techniques than Chinese firms. The Sri Lankan results marginally contrasted with Banda et al. (2014), who noted that Sri Lankan firms rely heavily on NPV, IRR and DPP, while the current evidence suggests that Sri Lankan firms tend to use PBP more than other CB techniques.

In Australia, the differences between males and females on the usage of $\mathrm{CB}$ techniques were insignificant in Australia and Sri Lanka except PBP $(t=-2.337 ; p<0.05)$ and DPP $(t=-2.045 ; p<0.05)$. Domestic vs foreign ownership does not significantly affect the choice of CB techniques in either Australia or Sri Lanka. This result is consistent with those for the Sri Lankan firms.

Table 4.

Capital budgeting process vs country, gender and ownership

\begin{tabular}{lcccrr}
\hline & \multicolumn{2}{c}{ Australia } & \multicolumn{2}{c}{ Sri Lanka } \\
Capital budgeting process & Country & Gender & Ownership & Gender & Ownership \\
\hline Long-term strategic planning & $-2.698^{* *}$ & -0.671 & -0.653 & 1.380 & 0.055 \\
Search for investment opportunities & -0.838 & 0.449 & -0.339 & -0.880 & 0.802 \\
Review and screening & 0.803 & $2.098^{* * *}$ & -1.498 & -1.166 & -0.696 \\
Accept/reject decisions & 0.053 & -1.521 & $2.296^{* *}$ & -0.518 & -0.828 \\
Implementation & $-4.931 * *$ & -0.484 & $-2.817^{* *}$ & -0.124 & -0.899 \\
Expenditure control and monitoring & $-4.347 * *$ & -0.604 & -1.200 & 1.748 & -0.475 \\
Post-audit & $-2.860^{* *}$ & -1.211 & 1.646 & 1.311 & -0.894 \\
Note(s): **Denotes a significantly different from zero at the 5\% level & & \\
\hline
\end{tabular}

Table 5.

Capital budgeting techniques vs country, gender and ownership

\begin{tabular}{llrrrr}
\hline & & \multicolumn{2}{c}{ Australia } & \multicolumn{2}{c}{ Sri Lanka } \\
Capital budgeting techniques & Country & Gender & Ownership & Gender & Ownership \\
\hline Payback period (PBP) & 0.885 & 1.866 & -1.355 & $-2.337 * *$ & 0.000 \\
Discounted payback period (DPP) & 0.259 & -0.314 & 0.921 & $-2.045^{* *}$ & 0.012 \\
Accounting rate of return (ARR) & $2.205^{* *}$ & 1.382 & 0.296 & -1.562 & 0.371 \\
Net present value (NPV) & $6.987^{* *}$ & -0.847 & -0.884 & -0.393 & 0.150 \\
Internal rate of return (IRR) & $6.221^{* *}$ & 1.118 & 1.703 & -1.290 & -0.598
\end{tabular}

Note(s): **Denotes a significantly different from zero at the $5 \%$ level 
4.1.3 Risk analysis techniques-Australia and Sri Lanka. Table 6 shows no significant differences between Australia and Sri Lanka on choice of risk assessment techniques, excluding sensitivity analysis $(t=4.219 ; p<0.05)$ and risk adjusted discount rate $(t=-2.607$; $p<0.05)$. In Australia and Sri Lanka, there are no significant differences between male and female on choice of risk assessment techniques. As regards the CFO's gender, it does not affect the risk assessment techniques for CB. In the case of Australian firms, there are no significant differences between domestic- and foreign-owned companies on choice of risk assessment techniques except decision tree approach $(t=-2.304 ; p<0.05)$.

4.1.4 Cost of capital-Australia and Sri Lanka. Table 7 indicates that there are no significant differences between Australia and Sri Lanka in estimating the cost of capital, excluding Weighted average cost of capital (WACC) $(t=2.082 ; p<0.05)$ and CAPM $(t=6.137 ; p<0.05)$. The results also indicate that most Australian and Sri Lankan firms rely to some extent on the WACC when estimating the cost of capital. In Australia and Sri Lanka, there are no significant differences between male and female CFOs on estimating cost of capital. In Australian, there are no significant differences between domestic- and foreignowned firms in estimating cost of capital except WACC $(t=2.085 ; p<0.05)$, whereas there are no obvious differences between domestic- and foreign-owned Sri Lankan firms on estimating cost of capital.

\subsection{One-way ANOVA}

4.2.1 Capital budgeting process-Australia and Sri Lanka. The results of the analysis of variance (ANOVA) were conducted to find the interaction between $\mathrm{CB}$ process and firm and its CFO's features in Australia and Sri Lanka. Tables 8 and 9 shows that there are no significant differences with use of CB process based on CFO's educational background in Australia except accept/reject decisions $(F=2.914, p<0.05)$ and implementation $(F=3.237$, $p<0.05$ ) whereas of the Sri Lanka results did not show any significant differences with CB process based on CFO's educational background except search for investment opportunities $(F=3.663, p<0.05)$, review and screening $(F=4.642, p<0.05)$ and post-audit $(F=3.484$,

\begin{tabular}{lccrrr}
\hline & & \multicolumn{2}{c}{ Australia } & \multicolumn{2}{c}{ Sri Lanka } \\
Risk assessment techniques & Country & Gender & Ownership & Gender & Ownership \\
\hline Scenario approach & -1.152 & -0.806 & -0.804 & -0.374 & -0.335 \\
Sensitivity analysis & $4.219 * *$ & 0.721 & -1.114 & 0.149 & 0.799 \\
Decision tree approach & 0.829 & 0.486 & $2.304 * *$ & -1.044 & -0.320 \\
Monte Carlo simulation & 1.044 & -0.339 & 1.671 & -1.184 & -0.885 \\
Risk adjusted discount rate & $-2.607^{* *}$ & -0.749 & 0.106 & -0.638 & -0.842 \\
Note(s): **Denotes a significantly different from zero at the 5\% level & &
\end{tabular}

Note(s): **Denotes a significantly different from zero at the $5 \%$ level

\section{Capital budgeting}

\begin{tabular}{lcrrrr}
\hline & & \multicolumn{2}{c}{ Australia } & \multicolumn{2}{c}{ Sri Lanka } \\
Cost of capital & Country & Gender & Ownership & Gender & Ownership \\
\hline Weighted average cost of capital (WACC) & $2.082^{* * *}$ & -0.697 & $2.085^{* * *}$ & -0.303 & -0.920 \\
Capital asset pricing model (CAPM) & $6.137^{* *}$ & -0.745 & -0.821 & -0.024 & 0.580 \\
Interest payable on debt capital & -1.607 & 0.135 & 0.496 & 1.893 & -1.376 \\
Dividend yield on shares & -1.168 & -1.345 & 1.218 & -1.024 & -0.935 \\
Earnings yield on shares & -0.651 & 0.000 & 1.471 & -0.005 & -1.657
\end{tabular}

Table 6.

Risk assessment techniques vs country, gender and ownership

Note(s): **Denotes a significantly different from zero at the $5 \%$ level

Table 7.

Cost of capital vs country, gender and ownership 


\section{PRR}

\section{Table 8.}

Australian capital budgeting process vs firm and its CFO's attributes

\begin{tabular}{|c|c|c|c|c|c|c|c|}
\hline $\begin{array}{l}\text { Capital budgeting } \\
\text { process }\end{array}$ & Education & Age & $\begin{array}{c}\text { CFO's } \\
\text { experience }\end{array}$ & $\begin{array}{l}\text { Australia } \\
\text { Industry }\end{array}$ & $\begin{array}{c}\text { No of } \\
\text { employees }\end{array}$ & $\begin{array}{c}\text { Domestic } \\
\text { income }\end{array}$ & $\begin{array}{c}\text { Risk } \\
\text { position } \\
\end{array}$ \\
\hline $\begin{array}{l}\text { Long-term } \\
\text { strategic planning }\end{array}$ & 1.245 & $3.519 * *$ & 2.138 & $3.997 * *$ & 0.381 & 0.467 & 0.234 \\
\hline $\begin{array}{l}\text { Search for } \\
\text { investment } \\
\text { opportunities }\end{array}$ & 0.810 & 2.116 & 1.123 & 1.822 & 0.851 & 0.321 & 1.098 \\
\hline $\begin{array}{l}\text { Review and } \\
\text { screening }\end{array}$ & 0.875 & 1.761 & $5.659^{* * *}$ & 1.642 & 0,591 & 0.453 & 1.295 \\
\hline $\begin{array}{l}\text { Accept/reject } \\
\text { decisions }\end{array}$ & $2.914 * *$ & $3.285^{* *}$ & $4.090 * *$ & $2.871 * *$ & 1.158 & 0.498 & $3.130^{* *}$ \\
\hline Implementation & $3.237 * *$ & $4.163^{* *}$ & 1.945 & $4.288 * *$ & 1.382 & 0.709 & $3.196^{* *}$ \\
\hline $\begin{array}{l}\text { Expenditure } \\
\text { control and } \\
\text { monitoring }\end{array}$ & 1.021 & 2.396 & $3.672^{* *}$ & $3.865^{* *}$ & 1.715 & 0.380 & 1.421 \\
\hline Post-audit & 1.335 & $3.063^{* *}$ & 1.053 & 1.148 & 2.112 & 0.986 & $2.948^{* *}$ \\
\hline
\end{tabular}

\begin{tabular}{|c|c|c|c|c|c|c|c|}
\hline $\begin{array}{l}\text { Capital budgeting } \\
\text { process }\end{array}$ & Education & Age & $\begin{array}{c}\text { CFO's } \\
\text { experience }\end{array}$ & $\begin{array}{l}\text { Sri Lanka } \\
\text { Industry }\end{array}$ & $\begin{array}{c}\text { No of } \\
\text { employees }\end{array}$ & $\begin{array}{l}\text { Domestic } \\
\text { income }\end{array}$ & $\begin{array}{c}\text { Risk } \\
\text { position }\end{array}$ \\
\hline $\begin{array}{l}\text { Long-term } \\
\text { strategic planning }\end{array}$ & 2.083 & $3.420 * *$ & $2.989^{* *}$ & $3.866^{* *}$ & 0.201 & 0.263 & $3.648^{* *}$ \\
\hline $\begin{array}{l}\text { Search for } \\
\text { investment } \\
\text { opportunities }\end{array}$ & $3.663 * *$ & 2.336 & 1.397 & 2.578 & 0.140 & 0.833 & 1.223 \\
\hline $\begin{array}{l}\text { Review and } \\
\text { screening }\end{array}$ & $4.642 * *$ & 1.820 & $3.469^{* *}$ & $3.675^{* *}$ & 1.396 & 0.052 & $4.300^{* *}$ \\
\hline Accept/reject & 1.599 & $3.397^{* * *}$ & 2.081 & 2.905 & 0.679 & 0.536 & $3.323^{* *}$ \\
\hline Implementation & 1.188 & 1.234 & $3.324^{* *}$ & $4.565^{* *}$ & 2.169 & 1.686 & 1.255 \\
\hline $\begin{array}{l}\text { Expenditure } \\
\text { control and } \\
\text { monitoring }\end{array}$ & 1.274 & $4.332 * *$ & 1.588 & $3.558^{* * *}$ & 0.307 & 0.972 & 1.337 \\
\hline Post-audit & $3.484 * *$ & 0.752 & 1.170 & 1.048 & $3.129^{* *}$ & 2.594 & 1.593 \\
\hline
\end{tabular}

$p<0.05)$. The results, also, reveal that the CB process in Australia varies with the CFO's age (except for search for investment opportunities, review and screening and expenditure control and monitoring) as indicated by the $F$-values. In contrast, in Sri Lanka, there are no significant differences with the $\mathrm{CB}$ process based on CFO's age except long-term strategic planning $(F=3.420, p<0.05)$, accept/reject decisions $(F=3.519, p<0.05)$ and expenditure control and monitoring $(F=3.519, p<0.05) . F$-statistics also show that there are no significant differences with $\mathrm{CB}$ process for CFO's experience except review and screening ( $F=5.659, p<0.05)$, accept/reject decisions $(F=4.090, p<0.05)$ and expenditure control and monitoring $(F=3.672, p<0.05)$ in Australia. In Sri Lanka, there are no significant differences with CB process based on CFO's experience except long term strategic planning $(F=2.989$, $p<0.05)$, review and screening $(F=3.469, p<0.05)$ and implementation $(F=3.324, p<0.05)$. ANOVA also reports an interaction between $\mathrm{CB}$ practices and industrial sector; the results 
show significant differences for long-term strategic planning $(F=3.997, p<0.05)$, accept/ reject decisions $(F=2.871, p<0.05)$, implementation $(F=4.288, p<0.05)$ and expenditure control and monitoring $(F=3.865, p<0.05)$ in Australia, while those of the Sri Lanka firms, the results show significant differences for long-term strategic planning $(F=3.558, p<0.05)$, review and screening $(F=3.675, p<0.05)$, implementation $(F=4.565, p<0.05)$ and expenditure control and monitoring $(F=3.866, p<0.05)$. In addition, the results did not find any significant differences with $\mathrm{CB}$ process based on number of employees in Australia while in Sri Lanka, there are no significant differences with CB process except post-audit $(F=3.129$, $p<0.05)$. The results also did not find any significant differences with $\mathrm{CB}$ practices for domestic income levels in Australia. This result is consistent with Sri Lankan firms. The results also revealed that there are significant differences with $\mathrm{CB}$ process based on risk position as indicated by the $F$-values such as accept/reject decisions $(F=3.130, p<0.05)$, implementation $(F=3.196, p<0.05)$ and post-audit $(F=2.948, p<0.05)$ in Australia whereas in those of Sri Lankan firms, there are significant differences with CB process based on risk position as indicated by the $F$-values such as long-term strategic planning $(F=3.648$, $p<0.05)$, review and screening $(F=4.300, p<0.05)$ and accept/reject decisions $(F=3.323$, $p<0.05)$. The empirical evidence suffices that $\mathrm{CB}$ process appears to be influenced by firm and CFO's attributes. It is exhibited that there is no structure guideline regarding CB process in Australia and Sri Lanka.

4.2.2 Capital budgeting techniques-Australia and Sri Lanka. The results of the ANOVA conducted to find the interaction between $\mathrm{CB}$ appraisal techniques and firm and its CFO'S attributes (Table 10) shows that there are no differences at significant level $p=0.05$ in the responses about the use of $\mathrm{PBP}$ in selecting investments due to firm and its CFO's attributes in Australia, whereas in Sri Lankan firms PBP has significant differences based on educational background with $F$-statistics $2.412(p<0.05) . F$-statistics presents that DPP is significantly related to industry sectors $(F=2.472 ; p<0.05)$ and number of employees $(F=3.267 ; p<0.05)$ in Australia, while in Sri Lankan firms reports on DPP, performed significantly different with educational background $(F=3.620 ; p<0.05)$, CFO's experience $(F=3.304 ; p<0.05)$, industry $(F=2.136 ; p<0.05)$, number of employees $(F=4.202 ; p<0.05)$ and domestic income level $(F=2.594 ; p<0.05)$. Based on ARR, there are significant differences among industry sectors in Australia; whereas ARR is significantly interrelated with educational background $(F=2.116 ; p<0.05)$ and domestic income level $(F=4.414 ; p<0.05)$. The results also revealed that the $p$-value which is less than 0.05 and the value of $F$-statistics is 4.011 and 2.862, respectively, for NPV and IRR

\begin{tabular}{|c|c|c|c|c|c|c|c|c|}
\hline & Education & Age & $\begin{array}{c}\text { CFO's } \\
\text { experience }\end{array}$ & Industry & $\begin{array}{c}\text { No of } \\
\text { employees }\end{array}$ & $\begin{array}{l}\text { Domestic } \\
\text { income }\end{array}$ & $\begin{array}{c}\text { Risk } \\
\text { position }\end{array}$ & \\
\hline \multicolumn{8}{|c|}{ Australia } & \\
\hline PBP & 0.552 & 0.797 & 1.057 & 1.780 & 1.308 & 0.059 & 1.449 & \\
\hline DPP & 1.447 & 0.159 & 0.789 & $2.472^{* *}$ & 3.267 ** & 2.367 & 1.210 & \\
\hline ARR & 1.169 & 0.034 & 0.196 & $2.305^{* *}$ & 2.804 & 2.538 & 0.562 & \\
\hline NPV & $4.011 * *$ & 0.533 & 2.823 & 0.979 & 0.857 & 0.068 & 0.544 & \\
\hline IRR & $2.862 * *$ & 0.533 & 0.823 & 0.591 & 0.224 & 1.158 & 0.871 & \\
\hline \multicolumn{8}{|l|}{$C B T$} & \\
\hline PBP & $2.412^{* *}$ & 1.073 & 0.995 & 0.527 & 2.105 & 1.383 & 1.693 & \\
\hline DPP & $3.620 * *$ & 2.981 & $3.304^{* *}$ & $2.136^{* * *}$ & $4.202^{* * *}$ & $2.594^{* * *}$ & 0.669 & \\
\hline ARR & $2.116 * *$ & 1.666 & 1.124 & 1.220 & 0.847 & $4.414^{* *}$ & 0.031 & Table 10. \\
\hline NPV & 1.197 & 0.633 & $3.937 * *$ & 0.310 & 2.265 & 1.793 & 0.435 & $\mathrm{CB}$ appraisal \\
\hline IRR & 0.702 & 1.232 & 2.187 & 0.536 & 0.609 & 0.141 & 0.787 & techniques vs firm and \\
\hline \multicolumn{9}{|c|}{ Note(s): ** Denotes a significantly different from zero at the $5 \%$ level } \\
\hline
\end{tabular}


which means there are significant differences between educational backgrounds in Australia. With Sri Lankan firms, based on NPV, there are significant differences between CFO's experience $(F=3.937 ; p<0.05)$ and based on IRR there are no significant differences between firm and its CFO's attributes. Based on scenario approach, there are no significant differences at significant level $p=0.05$ with respect to firm and its CFO's attributes in Australia and Sri Lanka. With Australian firms, sensitivity analysis differs significantly with respect to CFO's age $(F=3.839 ; p<0.05)$. In Sri Lanka, $F$-statistics indicates that sensitivity analysis differs significantly with respect to CFO's age $(F=4.507 ; p<0.05)$ and number of employees $(F=2.942 ; p<0.05)$. The results also reported that in Australia and Sri Lanka there are no significant differences in firm and its CFO's attributes concerning decision-tree approach. The use of probabilistic (Monte Carlo) simulation and risk adjusted discount rate is independent of CFO's attributes in Australia. With Sri Lankan firms, educational background does have significant influence on the use of probabilistic (Monte Carlo) simulation $(F=4.420 ; p<0.05)$ and, based on risk-adjusted discount rate, there are significant differences between educational background $(F=3.686$; $p<0.05)$ and number of employees $(F=3.230$; $p<3.230$ ). In Australian firms, WACC is independent of a firm's CFO attributes. This result is consistent with those for the Sri Lankan firms. On CAPM in Australia, there are significant differences in CFO's age groups $(F=5.032 ; p<0.05)$ and in Sri Lanka, CFO's age $(F=3.166 ; p<0.05)$, CFO's experience $(F=2.938 ; p<0.05)$, industrial sector $(F=2.107 ; p<0.05)$ and number of employees $(F=4.773 ; p<0.05)$. Based on interest payable on debt capital, there are no significant differences between firm and its CFO's attributes in Australia and Sri Lanka. The results reported that in relation to dividend yield on shares and earnings yield on shares in Australia, there are also no significant differences in firm and its CFO's attributes. This result is consistent with those for the Sri Lankan firms. In overall, the results of the study are similar to those of De Andrés et al. (2015), Hanaeda and Serita (2014), Daunfeldt and Hartwig (2014), Brunzell et al. (2013), Hassan et al. (2011), Brijlal (2009), Verma et al. (2009), Hermes et al. (2007), Brounen et al. (2004), and Sandahl and Sjogren (2003). Moreover, these results also were consistent with a study conducted by Al-Ajmi et al. (2011) which reported that firm and its CFO's attributes such as ownership, sources of revenue, etc. have some impact on decisions to adopt $\mathrm{CB}$ and method of estimating cost of capital and risk. The results are in sharp contrast with Farah et al. (2008) who found that there is no statistically significant relation between firm features and $\mathrm{CB}$ techniques. In the meantime, empirical research by Bennouna et al. (2010) produced results marginally inconsistent with current results that some of the large firms did not use DCF in Canada even as a developed country. It therefore can be confidently concluded that the $\mathrm{CB}$ analysis techniques depends on the level of influence of firm and its CFO's attributes (see Table 11).

\subsection{Multiple regression analysis}

Multiple regression analysis was performed to investigate the impact of $\mathrm{CB}$ practices and the CFO's attributes on firm performance measures (ROA, ROE, EPS and TQ) for which the models used for the study is given below (see Table 12).

The case of Australia: Table 13 shows that models using the drivers in Table 1 have goodto-strong predictive powers, vis-à-vis all firm-performance proxies except for $R O E$. This poor predictive power is sensible, given that the use of leverage is often more important to $R O E$ outcomes than business performance. The predictions of the three other firm-performance proxies are strong. Specifically, the $R^{2}$ values in Table 13 indicate that $53.1,38.4$ and $42.8 \%$ of the variability in, respectively, the $R O A, E P S$ and $T Q$ of Australian firms can be explained by 
the $\mathrm{CB}$ practices of the firm and $\mathrm{CFO}$ features. The $F$-statistics and significance levels (sig) in Tables 8 and 9 show that these three models generate statistically significant outcomes.

Table 14 shows that all variables do not have significant impact on $R O A$ excluding $C B P$ Capital
budgeting ( $B=79.497$ and $p=0.047)$, educational background $(B=-221.487$ and $p=0.009)$, number of employees and $(B=-770.762$ and $p=0.000)$ and except $C B T$, education background and number of employees all have positive signs. $C B P$ is statistically significant at $5 \%$ level while educational background and number of employees are statistically significant at $1 \%$ level. Although educational background and number of employees have negative signs, neither of them are statistically significant at $1 \%$ level. The results also indicate that all variables do not

\begin{tabular}{|c|c|c|c|c|c|c|c|}
\hline & Education & Age & $\begin{array}{c}\text { CFO's } \\
\text { experience }\end{array}$ & Industry & $\begin{array}{c}\text { No of } \\
\text { employee }\end{array}$ & $\begin{array}{l}\text { Domestic } \\
\text { income }\end{array}$ & $\begin{array}{c}\text { Risk } \\
\text { position }\end{array}$ \\
\hline$R A T$ & & & & Australia & & & \\
\hline Scenario & 2.130 & 1.576 & 0.549 & 1.461 & 2.274 & 1.516 & 0.607 \\
\hline Sensitivity & 0.701 & $3.839 * *$ & 0.672 & 0.370 & 1.460 & 1.406 & 1.427 \\
\hline Decision & 0.897 & 1.599 & 0.975 & 1.468 & 1.534 & 0.997 & 1.563 \\
\hline Monte & 0.924 & 0.965 & 0.325 & 1.338 & 2.524 & 2.210 & 1.214 \\
\hline $\begin{array}{l}R \text { adjusted } \\
R A T\end{array}$ & 0.294 & 0.863 & 1.082 & $\begin{array}{l}1.077 \\
\text { Sri Lanka }\end{array}$ & 0.270 & 1.759 & 0.540 \\
\hline Scenario & 1.216 & 2.070 & 1.579 & 0.499 & 1.293 & 1.386 & 0.506 \\
\hline Sensitivity & 1.354 & $4.507 * *$ & 1.045 & 2.005 & $2.942^{* * *}$ & 0.362 & 0.842 \\
\hline Decision & 1.477 & 0.294 & 0.729 & 1.337 & 0.288 & 0.762 & 0.076 \\
\hline Monte & 0.729 & $4.420^{* *}$ & 2.040 & 0.729 & 0.170 & 0.242 & 0.330 \\
\hline$R$ adjusted & 0.555 & $3.686^{* *}$ & 1.061 & 0.678 & $3.230^{* *}$ & 1.084 & 0.541 \\
\hline
\end{tabular}

Note(s): ** Denotes a significantly different from zero at the $5 \%$ level

Table 11.

Risk assessment techniques vs firm and its CFO's attributes

\begin{tabular}{|c|c|c|c|c|c|c|c|c|}
\hline & Education & Age & $\begin{array}{c}\text { CFO's } \\
\text { experience }\end{array}$ & Industry & $\begin{array}{c}\text { No of } \\
\text { employee }\end{array}$ & $\begin{array}{l}\text { Domestic } \\
\text { income }\end{array}$ & $\begin{array}{c}\text { Risk } \\
\text { position }\end{array}$ & \\
\hline$C C$ & \multicolumn{7}{|c|}{ Australia } & \\
\hline WACC & 0.514 & 0.641 & 2.182 & 1.377 & 0.469 & 1.225 & 1.225 & \\
\hline CAPM & 0.983 & 0.168 & 2.266 & 1.315 & $5.032^{* *}$ & 1.843 & 0.685 & \\
\hline IPOD & 0.381 & 0.291 & 0.584 & 1.577 & 0.741 & 2.103 & 0.512 & \\
\hline Dividend & 0.327 & 0.063 & 0.970 & 0.509 & 1.339 & 1.928 & 0.608 & \\
\hline Earnings & 1.026 & 0.442 & 0.059 & 1.170 & 0.765 & 0.781 & 0.263 & \\
\hline \multicolumn{8}{|l|}{$C C$} & \\
\hline WACC & 1.290 & 0.484 & 0.297 & 0.532 & 1.004 & 0.031 & 1.639 & \multirow{6}{*}{$\begin{array}{r}\text { Table } 12 . \\
\text { Cost of capital vs firm } \\
\text { and its CFO's } \\
\text { attributes }\end{array}$} \\
\hline CAPM & 0.795 & $3.166^{* *}$ & $2.938^{* *}$ & $2.107^{* *}$ & $4.773^{* *}$ & 0.416 & 1.005 & \\
\hline IPOD & 1.034 & 0.842 & 1.750 & 0.541 & 0.035 & 0.915 & 0.879 & \\
\hline Dividend & 0.850 & 2.703 & 0.422 & 1.501 & 1.626 & 0.814 & 1.156 & \\
\hline Earnings & 1.632 & 0.794 & 1.441 & 1.713 & 1.397 & 1.451 & 1.595 & \\
\hline \multicolumn{8}{|c|}{ Note(s): ** Denotes a significantly different from zero at the $5 \%$ level } & \\
\hline
\end{tabular}

\begin{tabular}{lllrrr}
\hline & $R O A$ & $R O E$ & $E P S$ & $T Q$ & \\
\hline$R$ & 0.729 & 0.467 & 0.620 & 0.654 & Predictors of $R O A$, \\
$R^{2}$ & 0.531 & 0.218 & 0.384 & 0.428 & $R O E, E P S$ and $T Q-$ \\
$F$-statistics & 4.399 & 1.087 & 2.425 & 2.910 & model summary \\
Significance levels & 0.001 & 0.397 & 0.029 & 0.011 & (Australia) \\
\hline
\end{tabular}




\section{PRR}

\begin{tabular}{|c|c|c|c|c|c|c|}
\hline \multirow[b]{2}{*}{ Models } & \multirow[b]{2}{*}{$R O A$} & \multirow[b]{2}{*}{$R O E$} & \multirow[b]{2}{*}{$E P S$} & \multirow[b]{2}{*}{$T Q$} & \multicolumn{2}{|c|}{$\begin{array}{c}\text { Collinearity } \\
\text { statistics }\end{array}$} \\
\hline & & & & & Tolerance & VIF \\
\hline Constant & $106.046(0.707)$ & $44.208(0.205)$ & $2.679(0.358)$ & $86.836(0.000)$ & na & na \\
\hline$C B P$ & $79.497(0.047)$ & $-6.523(0.177)$ & $0.292(0.469)$ & $-3.339(0.214)$ & 0.887 & 1.127 \\
\hline$C B T$ & $27.729(0.784)$ & $12.079(0.332)$ & $0.408(0.695)$ & $-1.589(0.818)$ & 0.879 & 1.137 \\
\hline $\begin{array}{l}\text { CFO_ } \\
\text { Education }\end{array}$ & $-221.487(0.009)$ & $-0.052(0.996)$ & $-2.207(0.011)$ & $1.516(0.781)$ & 0.782 & 1.279 \\
\hline CFO_Age & $103.393(0.262)$ & $-9.744(0.386)$ & $0.968(0.307)$ & $2.257(0.717)$ & 0.617 & 1.622 \\
\hline $\begin{array}{l}\text { CFO_- } \\
\text { Experience }\end{array}$ & $84.391(0.352)$ & $2.431(0.826)$ & $0.632(0.498)$ & $-9.716(0.120)$ & 0.587 & 1.704 \\
\hline $\begin{array}{l}\text { Firm_Size of } \\
\text { employees }\end{array}$ & $-770.762(0.000)$ & -12.621 (0.489) & $1.427(0.354)$ & $-15.137(0.141)$ & 0.858 & 1.165 \\
\hline $\begin{array}{l}\text { Firm_- } \\
\text { Domestic } \\
\text { income }\end{array}$ & 120.109 (0.184) & $2.798(0.798)$ & $-1.170(0.208)$ & $-0.307(0.960)$ & 0.854 & 1.171 \\
\hline $\begin{array}{l}\text { Firm_- } \\
\text { Ownership }\end{array}$ & $243.907(0.057)$ & $26.598(0.088)$ & $1.760(0.176)$ & $10.462(0.224)$ & 0.766 & 1.305 \\
\hline $\begin{array}{l}\text { Firm_Risk } \\
\text { level }\end{array}$ & $113.799(0.124)$ & $8.922(0.319)$ & $1.773(0.022)$ & $15.723(0.003)$ & 0.893 & 1.119 \\
\hline
\end{tabular}

have significant impact on $R O E$, but all have positive signs except $C B P$, educational background, age and numbers of employees. Moreover, the results revealed that all variables do not have a significant impact on $E P S$, except educational background $(B=-2.207$ and $p=0.011)$ and risk level $(B=1.773$ and $p=0.022)$ and except educational background and domestic income which have positive signs. The table shows that all variables do not have a significant impact on $T Q$ except risk level $(B=15.723$ and $p=0.003)$. Collinearity does not appear to be an issue, as all of the tolerance statistics are under 1.0 and all the VIF values are below 10.

In the case of Sri Lanka: Table 15 shows that models using the drivers in Table 1 through four have fair to poor predictive powers vis-a-vis all of the firm performance proxies. Specifically, CB practices and the characteristics of the firm and its CFOs generate $R^{2}$ of 0.186 , $0.151,0.117$ and 0.138 for, respectively, $R O A, R O E, E P S$ and $T Q$. These levels of correlation are not statistical significant as indicated by the corresponding $F$-values and significance levels of, respectively, $F=1.546$ and $p=0.152, F=1.203$ and $p=0.310, F=0.897$ and $p=0.534$, and $F=1.086$ and $p=0.387$.

Table 16 reveals that all variables do not have significant impact on $R O A$ excluding management experience $(B=28.104$ and $p=0.049)$ and risk level $(B=38.471$ and $p=0.016)$ and except $C B T$, age, number of employees and domestic income all have positive signs. Management experience and risk level are statistically significant at the $5 \%$ level. The only variables that significantly affects $R O E$ is ownership $(B=-27.693$ and $p=0.026)$, but all have positive signs except $C B T$, educational background, management experience, ownership and risk level. Also, the variables do not significantly affect $E P S$, other than

Table 15.

Predictors of $R O A$, $R O E, E P S$ and $T Q-$ model summary (Sri Lanka)

\begin{tabular}{lcccc}
\hline & $R O A$ & $R O E$ & $E P S$ & $T Q$ \\
\hline$R$ & 0.431 & 0.388 & 0.342 & 0.372 \\
$R^{2}$ & 0.186 & 0.151 & 0.117 & 0.138 \\
$F$-statistic & 1.546 & 1.203 & 0.897 & 1.086 \\
Significance levels & 0.152 & 0.310 & 0.534 & 0.387
\end{tabular}




\begin{tabular}{|c|c|c|c|c|c|c|c|}
\hline \multirow[b]{2}{*}{ Models } & \multirow[b]{2}{*}{$R O A$} & \multirow[b]{2}{*}{$R O E$} & \multirow[b]{2}{*}{$E P S$} & \multirow[b]{2}{*}{$T Q$} & \multicolumn{2}{|c|}{$\begin{array}{l}\text { Collinearity } \\
\text { statistics }\end{array}$} & \multirow[t]{2}{*}{$\begin{array}{l}\text { Capital } \\
\text { budgeting }\end{array}$} \\
\hline & & & & & Tolerance & $\mathrm{VIF}$ & \\
\hline Constant & $18.735(0.346)$ & $35.936(0.129)$ & $17.690(0.212)$ & $86.965(0.000)$ & na & na & \\
\hline$C B P$ & $3.416(0.129)$ & $1.544(0.559)$ & $0.762(0.631)$ & $2.529(0.178)$ & 0.938 & 1.066 & \\
\hline$C B T$ & $-6.401(0.230)$ & $-8.317(0.188)$ & $0.408(0.914)$ & $-3.054(0.492)$ & 0.881 & 1.136 & \\
\hline $\begin{array}{l}\text { CFO_- } \\
\text { Education }\end{array}$ & $7.483(0.153)$ & $-8.247(0.183)$ & $0.183(0.961)$ & $0.817(0.851)$ & 0.918 & 1.089 & \\
\hline CFO_Age & $-30.910(0.063)$ & 4.037 (0.835) & $-0.812(0.944)$ & $-29.564(0.034)$ & 0.260 & 3.843 & \\
\hline $\begin{array}{l}\mathrm{CFO}_{-} \\
\text {Experience }\end{array}$ & $28.104(0.049)$ & $-4.039(0.808)$ & $5.801(0.562)$ & $16.876(0.155)$ & 0.239 & 4.181 & \\
\hline $\begin{array}{l}\text { Firm_Size of } \\
\text { employees }\end{array}$ & $-11.115(0.205)$ & $12.294(0.236)$ & 4.849 (0.435) & $1.502(0.837)$ & 0.918 & 1.089 & \\
\hline $\begin{array}{l}\text { Firm- } \\
\text { Domestic } \\
\text { income }\end{array}$ & $-9.788(0.411)$ & $0.836(0.953)$ & $-12.304(0.149)$ & $-19.766(0.050)$ & 0.826 & 1.210 & \\
\hline $\begin{array}{l}\text { Firm_- } \\
\text { Ownership }\end{array}$ & $16.480(0.112)$ & $-27.693(0.026)$ & $-11.408(0.122)$ & $2.541(0.768)$ & 0.896 & 1.116 & $\begin{array}{l}\text { Table } 16 . \\
\text {. }\end{array}$ \\
\hline $\begin{array}{l}\text { Firm_Risk } \\
\text { level }\end{array}$ & $38.471(0.016)$ & $-16.477(0.375)$ & $0.384(0.973)$ & $5.416(0.679)$ & 0.625 & 1.600 & $\begin{array}{l}\text { predictors of } R O A \text {, } \\
R O E, E P S \text { and } T Q\end{array}$ \\
\hline \multicolumn{7}{|c|}{ Note(s): $p<0.01, p<0.05, p<0.1$ are statistically significant confidence level } & (Sri Lanka) \\
\hline
\end{tabular}

age, domestic income and ownership (each having a positive sign). Table 15 indicates that all variables have a significant impact on $T Q$, except CFO's age $(B=-29.564$ and $p=0.034)$, $C B T$, age and domestic income (which have positive signs). Collinearity does not appear to be an issue as all of the tolerance statistics are under 1.0 and all the VIF values are below 10.

\section{Conclusions, limitations and future research}

In evaluating the association between $\mathrm{CB}$ practices and the characteristics of the firm and its managers with firm performance in a developed country (Australia) and an emerging country (Sri Lanka), this paper sought to disentangle the firm nature from the nurture effects of the country in which the firm is embedded (i.e. the development level of the nation was taken as a proxy for such things as human capital availability, regulatory systems, market sophistications, etc.).

It was found that the nature of a firm tends to trump the nurture of the development level of the country in which the firm is embedded. While the Australian CB model was statistically clearer with generally more significant variables, it was also found that firm size matters in both countries and that larger firms in both countries tend to use more sophisticated $\mathrm{CB}$ methods than those of smaller firms in Sri Lanka. The cross-national discrepancies in the use of $\mathrm{CB}$ techniques revealed in this study show that major differences in the Australian and Sri Lankan economies and cultures are driving the variances in CB practices. The Australian business environment being much more competitive than that of Sri Lanka is suggested in the greater concern of the Australian respondents for the risks faced by their firms than what was expressed by their Sri Lankan colleagues. The Australian respondents appear to be much less procedured and rules bound (at all levels of the CB process) than their Sri Lankan counterparts. Another bit of evidence that Australia is more competitive than Sri Lanka is in the relatively high sophistication of Australian CB techniques. It is interesting to note that the $\mathrm{PBP}$ preference is consistently stronger in Sri Lanka, but use of PBP is not significantly lower in Australian firms. This suggests that, despite the many weaknesses and failings noted about PBP by academics, PBP still provides great comfort and value in the CB process- 
possibly as a rough-and-ready measure of relative risk that ensures that the decision makers do not get led up the garden path by the more sophisticated CB techniques. Also of great interest is that Australian firms are more likely to use multiple modes of $\mathrm{CB}$ appraisal techniques than Sri Lankan firms-perhaps because their appetite for risky investments appears to be significantly greater than that of their Sri Lankan counterparts. $n$ complex realworld situations, reconciling the outputs of a multifaceted approach to $\mathrm{CB}$ methods is more likely to give the depth and width of input needed to achieve an optimal capital investment plan. Concurrently as Sri Lanka passes through its post-war recovery phase, reform of its financial and capital market is essential to sustain economic growth and development. While a wider diffusion of better investment appraisal method in Sri Lankan firms could improve the cost-effectiveness of investment decisions and generally increase efficiency, this is unlikely to occur until competition is more of a spur.

The key limitations inherent in the use of any questionnaire survey were mitigated to a degree by using official and third-party sources of data were possible for the analysis. An added limitation is the difficulties inherent in discovering and adjusting for variations in the $\mathrm{CB}$ mechanisms, business scope and/or financing portfolio across firms. Like most previous studies, this study examines only selected firm-performance proxies. Difficulties arising from accounting standards and principles varying across countries have greatly eased over the past decade as International Financial Reporting Standards (IFRS) have increasingly been adopted and applied.

Future research should consider generating more generalised conclusions by expanding the study to include many more countries across the emerging-country to developed-country divide. Also, future research should expand consideration of the influence of firm size and sophistication on the $\mathrm{CB}$ process.

\section{References}

Al-Ajmi, J., Al-Saleh, N. and Hussain, H. (2011), "Investment appraisal practices: a comparative study of conventional and Islamic financial institutions", Advances in Accounting, Vol. 27, pp. 111-124.

Aldamen, H. and Duncan, K. (2012), "Does adopting good corporate governance impact the cost of intermediated and non-intermediated debt?", Accounting and Finance, Vol. 52, pp. 49-76.

Aldamen, H., Duncan, K., Kelly, S., McNamara, R. and Nagel, S. (2012), "Audit committee characteristics and firm performance during the global financial crisis", Accounting and Finance, Vol. 52, pp. 971-1000.

Alkaraan, F. and Northcott, D. (2006), "Capital investment decision making: a role for strategic management accounting", British Accounting Review, Vol. 38, pp. 149-173.

Andor, G., Mohanty, S. and Toth, T. (2015), "Capital budgeting practices: a survey of Central and Eastern European firms", Emerging Markets Review, Vol. 23, pp. 148-172.

Arnold, G. and Hatzopoulos, P. (2000), "The theory-practice gap in capital budgeting: evidence from the United Kingdom”, Journal of Business Finance and Accounting, Vol. 27, pp. 603-625.

Baker, K., Dutta, S. and Samir, S. (2011), "Management views on real options in capital budgeting", Journal of Applied Finance, Vol. 21, pp. 18-29.

Banda, W., Koralalage, Y., Ratnayake, C. and Mudiyanselage, R. (2014), "The use of capital budgeting techniques in large businesses: evidence from Sri Lanka", International Journal of Arts and Commerce, Vol. 3, pp. 77-84.

Batra, R. and Verma, S. (2014), “An empirical insight into different stages of capital budgeting”, Global Business Review, Vol. 15, pp. 339-362.

Bennouna, K., Meredith, G. and Marchant, T. (2010), "Improved capital budgeting decision making: evidence from Canada", Management Decision, Vol. 48, pp. 225-247. 
Brijlal, P. (2009), "The use of capital budgeting techniques in businesses: a perspective from the Western Cape", The Journal of Applied Business Research, Vol. 25, pp. 37-46.

Brounen, D., Jong, A. and Koedijk, K. (2004), "Corporate finance in Europe: confronting theory with practice”, Journal Financial Management, Vol. 33, pp. 1-40.

Brunzell, T., Liljeblom, E. and Vaihekoski, M. (2013), "Determinants of capital budgeting methods and hurdle rates in Nordic firms", Accounting and Finance, Vol. 53, pp. 85-110.

Chan, H., Kamal, H. and William, S. (2004), "Capital budgeting practices of Chinese firms", The Journal of Global Business Management, Vol. 1, pp. 20-26.

Chen, N. (1991), "Financial investment opportunities and the macro economy", Journal of Finance, Vol. 46, pp. 529-554.

Christy, G. (1966), Capital Budgeting Current Practices and Their Efficiency, University of Oregon.

Coltman, G. (1995), An Analysis of Capital Budgeting Techniques and Their Impact on Shareholder Wealth, University of Cape Town.

Daunfeldt, S. and Hartwig, F. (2014), "What determines the use of capital budgeting methods? Evidence from Swedish listed companies", Journal of Finance and Economics, Vol. 2, pp. 101-112.

De Andrés, P., De Fuente, G. and San Martín, P. (2015), “Capital budgeting practices in Spain”, BRQ Business Research Quarterly, Vol. 18, pp. 37-56.

Farah, M., Mansor, I. and George, W. (2008), "Capital budgeting practices of listed Indonesian companies”, Asian Journal of Business and Accounting, Vol. 1, pp. 175-192.

Farragher, E., Kleiman, R. and Sathu, A. (1999), "Current capital investment practices”, Engineering Economist, Vol. 44, pp. 137-141.

Farragher, E., Kleiman, R. and Sathu, A. (2001), "The association between the use of sophisticated capital budgeting practices and corporate performance", The Engineering Economist, Vol. 46, pp. 300-311.

Freeman, M. and Hobbes, G. (1991), "Capital budgeting: theory versus practice”, Australian Accountant, Vol. 61, pp. 36-41.

Gervais, S., Heaton, J. and Odean, T. (2012), "Overconfidence, compensation contracts, and capital budgeting”, The Journal of Finance, Vol. 66, pp. 1735-1777.

Graham, J. and Harvey, C. (2001), "The theory and practice of corporate finance: evidence from the field”, Journal of Financial Economics, Vol. 2, pp. 187-243.

Haka, S., Lawrence, A. and George, E. (1985), "Sophisticated capital budgeting selection techniques and firm performance", The Accounting Review, Vol. 9, pp. 651-669.

Han, C. (1986), "The sophistication of capital budgeting in Malaysian companies", Omega, Vol. 14, pp. 175-181.

Hanaeda, H. and Serita, T. (2014), "Capital budgeting practices: evidence from Japan”, available at: http://papers.ssrn.com/sol3/papers.cfm?abstract_id $=2312264$.

Hasan, H., Al Mutairi, M. and Risik, A. (2011), The Impact of Corporte Financing Decision on Corporate Performance in the Absence of Taxes: Panel Data from Kuwait Stock Market, pp. 1-27.

Hassan, M., Hosny, L. and Vasilya, S. (2011), "Capital investment practices: a survey of large corporation in developing market", Global Review of Accounting and Finance, Vol. 2, pp. 39-60.

Hermes, N., Smid, P. and Yao, L. (2007), "Capital budgeting practices: a comparative study of the Netherlands and China", International Business Review, Vol. 16, pp. 630-654.

Jog, M. and Srivastava, A. (1995), "Capital budgeting practices in corporate Canada", Financial Practice and Education, Vol. 5, pp. 37-43.

Kashyap, A. (2014), "Capital allocating decisions: time value of money", Asian Journal of Management, Vol. 5, pp. 106-110. 
Kester, G. and Chong, T. (1998), "Capital budgeting practices of listed firms in Singapore”, Sigapore Management Review, Vol. 20, pp. 9-23.

Kim, S.H. (1981), "An empirical study on the relationship between capital budgeting practices and earnings performance”, The Engineering Economist, Vol. 27, pp. 185-196.

Klammer, T. (1973), "The association of capital budgeting and firm performance", The Accounting Review, Vol. 48, pp. 353-364.

Klammer, T. and Walker, M. (1984), "The continuing increase in the use of sophisticated capital budgeting techniques", California Management Review, Vol. 27, pp. 137-148.

Lam, K., Wang, D. and Lam, M. (2008), "Practices of Hong Kong building contractors in strategic asset allocation process: longitudinal approach", Journal of Financial Management of Property and Construction, Vol. 13, pp. 176-186.

Manoj, A. (2002), “Corporate finance practices in India: a survey”, Vikalpa, Vol. 27, pp. 29-56.

Maroyi, V. and Van Der Poll, V. (2012), "A survey of capital budgeting techniques used by listed mining companies in South Africa", African Journal of Business Management, Vol. 6, pp. 9279-9292.

Mintzberg, H., Raisinghini, D. and Theoret, A. (1976), "The structure of unstructured decision processes", Administrative Science Ouarterly, Vol. 21, pp. 246-275.

Mustapha, M. and Mooi, S. (2001), "Firm performance and degree of sophistication of capital budgeting practice: some Malaysian evidence", Proceedings of the Asia Pacific Management Conference, Kuala Lumpur, pp. 279-290.

Northcott, D. (1995), Capital Investment Decision Making, Dryden Press, London.

Peel, M. (1999), "Planning, business objectives and capital budgeting in Japanese, German and domestic SMEs: some evidence from the UK manufacturing sector", Journal of Small Business and Enterprise Development, Vol. 6, pp. 350-365.

Peterson, P. and Fabozzi, F. (2002), Capital Budgeting: Theory and Practice, John Wiley and Sons, New York, available at: http://160592857366.free.fr/joe/ebooks/tech/Wiley\%20Capital\%20Budgeting $\% 20$ Theory $\% 20$ and $\% 20$ Practice.pdf.

Pike, R. (1984), "Sophisticated capital budgeting systems and their association with corporate performance", Managerial and Decision Economics, Vol. 5, pp. 91-97.

Pike, R. (1988), "An empirical study of the adoption of sophisticated capital budgeting practices and decision-making effectiveness", Accounting and Business Research, Vol. 18, pp. 341-351.

Pinches, G. (1982), "Myopia, capital budgeting and decision making", Financial Management, Vol. 11, pp. 6-19.

Pradeep, B. and Lemay, Q. (2009), "The use of capital budgeting techniques in business: a perspective from the western cape", The Journal of Applied Business Research, Vol. 25, pp. 37-46.

Proctor, M. and Canada, J. (1992), "Past and present methods of manufacturing investment evaluation: a review of the empirical and theoretical literature", The Engineering Economist, Vol. 38, pp. $45-58$.

Ruhan, A. (1998), "Malaysian capital budgeting methods: survey and analysis", Annual PACAP/FMA Finance Conference on Asia Pacific Financial Market, Kuala Lumpur.

Sandahl, G. and Sjogren, S. (2003), "Capital budgeting methods among Sweden's largets groups of companies", Production Economics, Vol. 84, pp. 51-69.

Satish, V., Sanjeev, G. and Roopali, B. (2009), "A survey of capital budgeting practices in corporate India”, The Journal of Business Perspective, Vol. 13, pp. 1-17.

Shao, L. and Alan, S. (1996), "Risk analysis and capital budgeting techniques of U.S. multinational enterprises”, Managerial Finance, Vol. 22, pp. 41-57.

Singh, S., Jain, P.K. and Yadav, S.S. (2012), "Capital budgeting decisions: evidence from India”, Journal of Advances in Management Research, Vol. 9, pp. 96-112. 
Sulaiman, K. (2007), "Capital investment appraisal practices of quoted firms in Nigeria”, available at: http://ssrn.com/abstract $=1000075$ or doi: $10.2139 /$ ssrn.1000075.

Truong, G., Partington, G. and Peat, M. (2008), "Cost-of-capital estimation and capital-budgeting practice in Australia", Australian Journal of Management, Vol. 33, pp. 95-122.

Vadeei, M., Mahmoudi, P. and Saeid, A. (2012), "An analysis and explanation of the relationship between techniques of capital budgeting and the performance of companies admitted to Tehran stock exchange", Journal of Basic and Applied Scientific Research, Vol. 2, pp. 6420-6423.

Van Horne, J., Wachowicz, J., Davis, K., Jr and Lawriwsky, M. (1995), Financial Management and Policy in Australia, 4th ed., Prentice-Hall, Sydney.

Verma, S., Gupta, S. and Batra, R. (2009), "A survey of capital budgeting practices in corporate India", The Journal of Business Perspective, Vol. 13, pp. 1-17.

Vijay, J. and Ashwani, S.S. (1995), "Capital budgeting practices in corporate Canada”, Journal of Financial Management, Vol. 1, pp. 37-43.

Wnuk-Pel, T. (2014), "Capital budgeting practices in non manufacturing firms in Poland", Social Sciences, Vol. 82, pp. 59-69.

\section{Corresponding author}

Pratheepkanth Puwanenthiren can be contacted at: ppratheep@univ.jfn.ac.lk

For instructions on how to order reprints of this article, please visit our website:

www.emeraldgrouppublishing.com/licensing/reprints.htm

Or contact us for further details: permissions@emeraldinsight.com 